\title{
Stability-indicating RP- HPLC -DAD method for the simultaneous estimation of Tramadol HCl and Diclofenac sodium
}

\author{
Ramalingam Peraman ${ }^{1}$, D. Subba Rao ${ }^{2}$, Rajesh Reddy Kadiri ${ }^{*}$, Amaranatha Reddy Bommireddy ${ }^{3}$ \\ ${ }^{1}$ Analytical Research Laboratory, Raghavendra Institute of Pharmaceutical Education and Research (RIPER), K R Palli Cross, Near SK University, \\ Anantapur Dt, Andhra Pradesh, India. ${ }^{2}$ Department of Chemical Engineering, Jawaharlal Nehru Technological University Anantapur, Andhra Pradesh, \\ India. ${ }^{3}$ Analytical research and development, Apotex Research Private Limited, Bangalore, Karnataka, India.
}

\section{ARTICLE INFO}

Article history:

Received on: 21/12/2016

Accepted on: 21/02/2017

Available online: 30/09/2017

\section{Key words:}

RP-HPLC, Simultaneous,

Tramadol, Diclofenac,

stability-indicating.

\begin{abstract}
A Specific stability-indicating high performance liquid chromatographic method was developed and validated for the determination of Tramadol $\mathrm{HCl}$ and Diclofenac sodium in a tablet dosage form. The separation was achieved on a reverse phase C18 column (Agilent ODS) $(250 \times 4.6 \mathrm{~mm}, 5 \mu \mathrm{m})$ with mobile phase consisted of methanol:water (61:39\% v/v containing 0.2\% HSA, pH 3.0 adjusted with Orthophosphoric acid) and the eluents were detected at $219 \mathrm{~nm}$. The retention time of Tramadol $\mathrm{HCl}$ and Diclofenac sodium was 5.9 min and $26.30 \mathrm{~min}$ respectively with the flow rate of $1 \mathrm{ml} / \mathrm{min}$. Drugs were subjected to stress conditions of acidic, basic, oxidation, photolytic, neutral and thermal degradation, considerable degradants were detected in all stress conditions. The method resulted in detection of 17 degradation products (D1 - D17), among those products, structures of D2, D9, D10, D12, D14, D15 and D16 were identified. The response of linear was in the range 5$50 \mu \mathrm{g} / \mathrm{ml}$ for Tramadol $\mathrm{HCl}$ and 10 to $70 \mu \mathrm{g} / \mathrm{ml}$ for Diclofenac sodium, respectively. Intra day precision was the range of $0.83-1.34(\% \mathrm{RSD})$ for Tramadol and $0.27-0.93(\% \mathrm{RSD})$ for Diclofenac. Inter day precision was the range of 1.33-1.81(\% RSD) for Tramadol and 0.96-1.32(\% RSD) for Diclofenac. Recoveries ranged in between $98-102 \%$.
\end{abstract}

\section{INTRODUCTION}

Diclofenac Sodium (DIC) is chemically, sodium;2-[2(2,6-dichloroanilino)phenyl]acetate, used as non-steroidal antiinflammatory agent and is official in BP, USP. It acts by the inhibition of leukocyte migration and the enzyme cyclooxygenase (COX-1 and COX-2), leading to the peripheral inhibition of prostaglandin synthesis. Tramadol $\mathrm{HCl}$ (TRA) is chemically, cis-2-[(dimethyl amino) methyl]-1-(3-methoxy phenyl) cyclohexanol $\mathrm{HCl}$, used mainly as analgesic and narcotic and is official in IP, BP \& USPNF. It is a centrally acting opioid like drug and acts by binding to the $\mu$ opiate receptors, where it is a pure agonist like morphine. Its mechanism of action is to

\footnotetext{
* Corresponding Author

Email: rajeshreddy.kadhiri@gmail.com
}

weakly increase both serotonin and nor-adrenaline spinal cord concentrations by re-uptake (PubChem). The literature for various analytical methods for DIC revealed that some UV Spectrophotometric (Patel et al., 2012; Ali et al., 2012) and simultaneous HPLC assay methods (Panda et al.,2012, Rathnam et al., 2010), Bioanalytical LC method (Degwy et al., 2013) stability indicating HPLC methods (Jadhav et al., 2015) and GC methods (Rajeevkumar et al., 2011) have been reported for Diclofenac Sodium alone or along with other drugs such as Paracetamol, camylofin, Chlorzoxazone, Methocarbamol, Ibuprofen, Metaxalone, Thiocolchicoside and Drotaverine. Reports on analytical methods for TRA revealed that an UV Spectrophotometric (Jignesh et al., 2011 ) and simultaneous HPLC assay methods (Keyur et al., 2012, Chandra et al., 2012) and stability indicating HPLC method (Rajesh et al., 2012) have been found in literature reported for tramadol dosage form alone or in combination with other drugs like Paracetamol, Aceclofenac and Domperidone. 
However, few UV (Patel et al., 2012, Anantha et al., 2009) HPLC methods (Teja deepthi et al., 2013) for simultaneous estimation of these drugs have been reported. Detailed study revealed that none of the method revealed all possible impurities nor attempted for identification of degradants. An extensive review of literature did not revealed any stability indicating RPHPLC method for the simultaneous analysis of DIC and TRA. Hence there is a need to develop stability indicating assay method for simultaneous analysis of DIC and TRA and to demonstrate and identify possible degradation products which are likely to form in long term storage conditions of their products. The tablet dosage form containing DIC (75 mg and TRA $50 \mathrm{mg}$ ) was approved in November 2011 by Central Drugs Standards Control Organization (CDSCO), Government of India. The formulation is approved as bilayer tablet in which DIC incorporated in sustained release layer and TRA incorporated immediate release layer. It is under development stage for the symptomatic treatment of moderate to severe pain in adults. However, few UV (Patel et al., 2012, Anantha et al., 2009) HPLC methods (Teja deepthi et al., 2013) for simultaneous estimation of these drugs have been reported. To date, no stability Indicating HPLC method has been reported, so there is a need to develop stability indicating assay method for simultaneous analysis of DIC and TRA.

\section{EXPERIMENTAL}

\section{Materials and Reagents}

Samples of Tramadol $\mathrm{HCl}$ and Diclofenac Sodium were obtained as gift sample from Aurobindo Pharma Ltd, Hyderabad Pvt. Ltd (India). Tablet formulation of Tramadol $\mathrm{HCl}$ and Diclofenac Sodium were procured from commercial market. All the solutions were protected from light and were analyzed on the day of preparations. Glass wares used in each procedure were soaked overnight in a mixture of chromic acid and sulphuric acid rinsed thoroughly with double distilled water and dried in hot air oven. All the reagents were of analytical-reagent (AR) grade unless stated otherwise. Millipore water, HPLC grade methanol, nheptane sulfonic acid (HSA), ortho phosphoric acid (OPA) solution were procured from Merck, India. Borosilicate (Class A) glass wares were used. The impurities D2, D14, D16 procure from Sigma Aldrich Ltd, wheras D9, D10, D12, D15 are well established impurities (RS) and are official in pharmacopoeia. These impurities were isolated through flash LC system and were used for identification.

\section{Instrumentation}

HPLC analysis was performed with Agilent-1200 binary pump plus manual sampler and Agilent photo diode-array detector (PDA). The output signal was monitored and processed using Ezchrome Elite software resident in a Pentium computer (Digital Equipment). Compounds were separated on a $250 \mathrm{~mm}-4.6 \mathrm{~mm}$ (id), $5 \mu \mathrm{m}$ particle size, Agilent $\mathrm{C}_{18}$ column with methanol and water $(61: 39 \mathrm{v} / \mathrm{v})$ with $0.2 \%(w / v)$ n-heptanesulfonicacid (HSA), and $\mathrm{pH}$ of aqueous phase was adjusted to 3.0 with ortho phosphoric acid
(OPA) as mobile phase. The injection volume was $20 \mu \mathrm{L}$ and eluents detected at $219 \mathrm{~nm}$ with the flow rate $1.0 \mathrm{ml} / \mathrm{min}$.

\section{Analysis of Formulation}

The assay of commercial tablets was established with present chromatographic condition developed and it was found to be more accurate and reliable. To determine the content of TRA and DIC in conventional tablet (50mg TRA/75mg DIC) twenty tablets were weighed; their mean weight was determined and was finely powdered. Tablet powder equivalent to $20 \mathrm{mg}$ TRA with relevant quantities of DIC was weighed and transferred to a 100 $\mathrm{ml}$ volumetric flask, extracted for $30 \mathrm{mins}$ with methanol and volume was made up to $100 \mathrm{ml}$ with diluents(methanol). $1 \mathrm{ml}$ of above solution was taken in $10 \mathrm{ml}$ volumetric flask and volume was made up to $10 \mathrm{ml}$ with mobile phase, and final solution $(20 \mu \mathrm{g}$ TRA, $30 \mu \mathrm{g}$ DIC/ml) was filtered through $0.45 \mu$ millipore filter and it was analyzed by HPLC system, as shown in Table 1.

Table 1: Analysis of Commercial Formulation $(n=6)$.

\begin{tabular}{cccc}
\hline $\begin{array}{c}\text { Label claim } \\
(\mathbf{m g} / \text { tablet})\end{array}$ & $\begin{array}{c}\text { Amount Found } \\
(\mathbf{m e a n} \pm \mathbf{S D})\end{array}$ & $\begin{array}{c}\text { Assay } \\
(\boldsymbol{\%})\end{array}$ & $\begin{array}{c}\text { \% } \\
\text { RSD }\end{array}$ \\
\hline TRA-50 & $49.12 \pm 0.66$ & 98.2 & 1.31 \\
DIC-75 & $74.17 \pm 0.65$ & 98.8 & 0.83 \\
\hline
\end{tabular}

\section{Preparation of standard drug solutions}

Stock solution of Tramadol $\mathrm{HCl}$ and Diclofenac Sodium was prepared by dissolving $10 \mathrm{mg}$ of each in separate $10 \mathrm{~mL}$ of volumetric flask with small quantity of methanol. The mixture was sonicated for about $5 \mathrm{~min}$ and then made up to volume with methanol. From the stock solution final concentrations was prepared.

\section{Forced Degradation Studies}

Forced degradations of drug substances were carried out under neutral, acidic, basic, oxidative, thermal and photolytic stress conditions. In stress study, aliquots of stress sample were diluted with mobile phase to a concentration of $100 \mu \mathrm{g} / \mathrm{ml}$. The $\mathrm{pH}$ of stress sample was adjusted to $3-4$ and injected in optimized condition with appropriate blank. The samples from acid hydrolysis were neutralized with $1 \mathrm{~N} \mathrm{NaOH}$ and the samples from base hydrolysis were neutralized with $1 \mathrm{~N} \mathrm{HCl}$.

\section{Preparation of Stock Solution for stress studies}

$10 \mathrm{mg}$ of each drug substance was accurately weighed and transferred in to $10 \mathrm{ml}$ volumetric flask, dissolved completely in methanol and the volume was made up to get $1000 \mu \mathrm{g} / \mathrm{ml}$. The same procedure was adapted to prepare stress solutions of acid hydrolysis, base hydrolysis and oxidative stress respectively with $1 \mathrm{~N} \mathrm{HCl}, 1 \mathrm{~N} \mathrm{NaOH}$ and $3 \% \mathrm{H}_{2} \mathrm{O}_{2}$. Thermal degradation was carried out for solid state samples by heating in hot air oven at $100^{\circ} \mathrm{C}$ for a period of $2 \mathrm{hr}$. Photo degradation was carried for solution samples under sunlight. In all stress studies, stress was induced for TRA (control), DIC (control) and for combination of both. Result of degradation studies of TRA and DIC was compared with their control and blank. 


\section{Hydrolysis}

The stock solutions of $1000 \mu \mathrm{g} / \mathrm{ml}$ were prepared in $1 \mathrm{~N}$ $\mathrm{NaOH}$ (Basic), $1 \mathrm{~N} \mathrm{HCl} \mathrm{(Acidic)} \mathrm{and} \mathrm{water} \mathrm{(neutral)} \mathrm{at} \mathrm{room}$ temperature. $1 \mathrm{ml}$ volume of sample was withdrawn at different time points and made to $10 \mathrm{ml}$ with mobile phase $(100 \mu \mathrm{g} / \mathrm{ml})$. The samples were neutralized to $\mathrm{pH} 3-4$ to protect the silica based column. Blank solutions for each hydrolysis were prepared at the same time of preparation of stock solutions. Both blank and samples were injected in optimized condition.

\section{Hydrogen Peroxide-Induced Degradation}

$1 \mathrm{ml}$ of sample solution was withdrawn from stock solution $(1000 \mu \mathrm{g} / \mathrm{ml})$ containing oxidizing agent $\left(\mathrm{H}_{2} \mathrm{O}_{2}\right)$ and transferred into $10 \mathrm{ml}$ volumetric flask. The volume was made up to the mark to get the $100 \mu \mathrm{g} / \mathrm{ml}$ and injected in optimized conditions at various time intervals against blank.

\section{Thermal Degradation}

For, Solid state stability, it was performed on preheated sample at $100^{\circ} \mathrm{C}$. At various time intervals, $10 \mathrm{mg}$ of samples were weighed, dissolved in methanol and suitably diluted to a concentration of $100 \mu \mathrm{g} / \mathrm{ml}$ and injected into the system.

\section{Photochemical Degradation}

Photo degradation studies were conducted by exposing the solution sample in sunlight for a total period of $12 \mathrm{hr}$. After degradation, sample was suitably diluted in mobile phase to a concentration of $100 \mu \mathrm{g} / \mathrm{ml}$ and then injected.

\section{Identification of impurities}

Impurities namely, 3-hydroxybenzoic acid (D2), 3-( (dimethyleamino) methyl) cyclohexanone (D9), (2(4methoxyphenyle) cyclohex-2enyle)-N,N-dimethyle methanamine (D10), ( 2-(2,6-dichlorophenyleamino)phenyl) methanol (D12), 2(2-hydroxyphenyle) acetic acid D(14), 1-(2,6dichlorophenyle)indolin-2-one $\mathrm{D}(15)$, 2,6-dichlorobenzeneamine $\mathrm{D}(16)$ suitably dissolved and diluted in mobile phase at a concentration of $100 \mu \mathrm{g} \mathrm{ml}^{-1}$ and spiked with injection of standards of DIC and TRA under optimized chromatographic conditions. Retention time of the impurities was compared with the degradation products of stress studies. It was identified that D2, D9 and D10 belong to tramadol, while D12, D14, D15 and D16 belong to diclofenac.

\section{RESULTS}

\section{Optimized conditions}

In this communication, the method was optimized on Agilent Qualisil ODS column C18 $(25 \mathrm{~cm} \times 4.6 \mathrm{~mm}$; particle size $5 \mu \mathrm{m})$ with a mobile phase composition methanol - water 61: 39 $\% v / v$, containing $0.2 \%$ n-heptanesulphonicacid (HSA); $\mathrm{pH}$ adjusted to 3.0. The flow rate was $1 \mathrm{ml} / \mathrm{min}$ and the photo diode array (PDA) detection wavelength was $219 \mathrm{~nm}$. Retention times were optimized to $5.90 \pm 0.2 \mathrm{~min}$ and $26.3 \mathrm{~min}$, respectively for
TRA and DIC. The retention time of diclofenac window was observed between 24.5 to $27.5 \mathrm{~min}$. It is absolutely due to effect of HSA concentration, $\mathrm{pH}$ and varied void volume. However the specificity and \%RSD for diclofenac were within the limit.

\section{Validation of the Stability-Indicating Method}

Method was validated as per ICH (Q2) guidelines with respect to specificity, linearity and range, accuracy, precision, robustness, limit of detection and limit of quantification (ICH Q2).

\section{Specificity}

Forced degradation studies were performed on TRA and DIC to support the specificity of the stability- indicating method. The study was employed on degradation of TRA and DIC by exposing to sun light (for $12 \mathrm{hr}$ ), heat $\left(100{ }^{\circ} \mathrm{C}\right.$ for $2 \mathrm{hr}$ ), acid hydrolysis (1 N HCl, kept at RT for $12 \mathrm{hr}$ ), base hydrolysis (1 N $\mathrm{NaOH}$, kept at RT for $48 \mathrm{hr}$ ), water hydrolysis (kept at RT for 5 days) and oxidation ( $3 \% \mathrm{H}_{2} \mathrm{O}_{2}$, kept at $\mathrm{RT}$ for 3 days). All degradants adequately separated from

TRA and DIC, thus the specificity of the method was proven. The peak purity was assessed based on purity angle and purity threshold in which both degraded and control samples chromatogram showed peak purity in the range of 0.9981-0.9998.

\section{Linearity and Range}

The linearity of the method was proven at concentrations of TRA and DIC in the range 5- $50 \mu \mathrm{g} / \mathrm{ml}$ and $10-70 \mu \mathrm{g} / \mathrm{ml}$, respectively (Table 2). The correlation coefficient ( $\mathrm{r} 2$ value) obtained was 0.9990 for TRA and 0.9999 for DIC, as shown in Table 2.

Table 2: Regression parameters, LOD and LOQ.

\begin{tabular}{ccc}
\hline Validation parameters & TRA & DIC \\
\hline Linearity and Range & $5-50 \mu \mathrm{g} / \mathrm{ml}$ & $10-70 \mu \mathrm{g} / \mathrm{ml}$ \\
Regression equation & $\mathrm{y}=79589 \mathrm{x}-58844$ & $\mathrm{y}=94108 \mathrm{x}+988975$ \\
Correlation coefficient $\left(R^{2}\right)$ & 0.9990 & 0.9999 \\
Limit of Quantification & 1.26 & 0.99 \\
$(\mu \mathrm{g} / \mathrm{ml})$ & & \\
Limit of Detection $(\mu \mathrm{g} / \mathrm{ml})$ & 0.42 & 0.33 \\
\hline
\end{tabular}

\section{Precision}

The $\%$ RSD for intraday and interday precision studies were obtained from three different concentrations $(5,30$ and 50 $\mu \mathrm{g} / \mathrm{ml}$ for TRA and 10,50 and $70 \mu \mathrm{g} / \mathrm{ml}$ for DICs) within linearity range. The $\%$ RSD values for intraday and interday precision were below $1.5 \%$, indicated that the method was sufficiently precise, as shown in Table 3.

\section{Recovery Studies}

Accuracy was performed by recovery studies using standard addition method. Standard drugs in the range of 80,100 and $120 \%$ of the sample concentration were added into the sample solution. Each concentration was analyzed in triplicate. Results of recovery studies were found to be in between 98 to $102 \%$ for both TRA and DIC, as shown in Table 4. 
Table 3: Precision Studies

\begin{tabular}{|c|c|c|c|c|c|}
\hline \multirow[b]{2}{*}{ Drug } & \multirow{2}{*}{$\begin{array}{c}\text { Amount } \\
(\mu \mathrm{g} \mathrm{mL-1})\end{array}$} & \multicolumn{2}{|c|}{ Intraday $(\mathrm{n}=3)$} & \multicolumn{2}{|c|}{$\operatorname{Interday}(n=3)$} \\
\hline & & $\begin{array}{c}\text { Amount found } \\
\text { Mean } \pm \text { SD }\end{array}$ & $\%$ RSD & $\begin{array}{c}\text { Amount found } \\
\text { Mean } \pm \text { SD }\end{array}$ & \% RSD \\
\hline \multirow{3}{*}{ TRA } & 5 & $5.16 \pm 0.06$ & 1.16 & $4.87 \pm 0.068$ & 1.4 \\
\hline & 30 & $29.43 \pm 0.4$ & 1.3 & $31.22 \pm 0.468$ & 1.5 \\
\hline & 50 & $50.12 \pm 0.5$ & 0.99 & $49.45 \pm 0.890$ & 1.8 \\
\hline \multirow{3}{*}{ DIC } & 10 & $9.96 \pm 0.029$ & 0.29 & $9.21 \pm 0.101$ & 1.1 \\
\hline & 50 & $49.65 \pm 0.099$ & 0.2 & $51.55 \pm 0.463$ & 0.9 \\
\hline & 70 & $70.23 \pm 0.632$ & 0.9 & $69.55 \pm 0.904$ & 1.3 \\
\hline
\end{tabular}

Table 4: Recovery studies ( $\mathrm{n}=3)$.

\begin{tabular}{|c|c|c|c|c|c|c|}
\hline \multirow{2}{*}{$\begin{array}{l}\text { Recovery } \\
\text { Level }\end{array}$} & \multicolumn{3}{|r|}{ TRA } & \multicolumn{2}{|l|}{ DIC } & \multirow[b]{2}{*}{$\begin{array}{c}\% \\
\text { Recovery }\end{array}$} \\
\hline & $\begin{array}{c}\text { Amount } \\
\text { Added }(\mu \mathrm{g} / \mathrm{ml})\end{array}$ & $\begin{array}{c}\text { Amount } \\
\text { Recovered }(\mu \mathrm{g} / \mathrm{ml})\end{array}$ & $\begin{array}{c}\% \\
\text { Recovery }\end{array}$ & $\begin{array}{c}\text { Amount } \\
\text { Added }(\mu \mathrm{g} / \mathrm{ml})\end{array}$ & $\begin{array}{c}\text { Amount } \\
\text { Recovered }(\mu \mathrm{g} / \mathrm{ml})\end{array}$ & \\
\hline $80 \%$ & 16 & 16.26 & 101.6 & 24 & 23.71 & 98.8 \\
\hline $100 \%$ & 20 & 19.86 & 99.3 & 30 & 29.68 & 98.8 \\
\hline $120 \%$ & 24 & 23.84 & 99.4 & 36 & 36.01 & 100.0 \\
\hline
\end{tabular}

Table 5: Comparative study of degradation data of DIC and TRA: Control Vs Combination.

\begin{tabular}{|c|c|c|c|c|c|c|c|c|}
\hline \multirow{3}{*}{$\begin{array}{c}\text { Stress } \\
\text { (Conditions) }\end{array}$} & \multicolumn{4}{|c|}{ \% degradation } & \multicolumn{4}{|c|}{ Impurities $\left(D_{\mathrm{X}}\right) \mathrm{x}=1,2,3 \ldots$} \\
\hline & \multicolumn{2}{|c|}{ Control } & \multicolumn{2}{|c|}{ Combination } & \multicolumn{2}{|c|}{ Control } & \multicolumn{2}{|r|}{ Combination } \\
\hline & TRA & DIC & TRA & DIC & TRA & DIC & TRA & DIC \\
\hline Neutral (5 days) & 10.1 & -- & 11.2 & 0 & D2, D4 & -- & D2, D4 & -- \\
\hline $1 \mathrm{~N} \mathrm{HCl}(12 \mathrm{~h})$ & 10.1 & 35.3 & 9.8 & 29 & D1 & D8, D11, D12, D17 & D1 & D8, D11, D12, D17 \\
\hline $1 \mathrm{~N} \mathrm{NaOH}(48 \mathrm{~h})$ & 14.4 & 7.4 & 12.3 & 7.9 & D1, D4 & --- & D1, D4 & --- \\
\hline Peroxide $(72 \mathrm{~h})$ & 9.8 & 8.7 & 14.5 & 9.6 & D1, D2 & D15 & D1, D2 & D15 \\
\hline Thermal $100^{\circ} \mathrm{C} ; 2 \mathrm{~h}$ & 17.5 & 5.2 & 18.6 & 10.3 & D3, D4, D9, D10 & D5, D6 & D3, D4, D9,D10 & D5, D6 \\
\hline Sunlight $12 \mathrm{~h}$ & 11.3 & 23.5 & 15.2 & 30.4 & D4, D9, D10 & D7, D8, D12, D13, D14, & D4, D9, D10 & D7, D8, D12, D13, D14, D16 \\
\hline
\end{tabular}

$\overline{\mathrm{R}_{\mathrm{t}}(\mathrm{min}) \text { of impurities: D1: 3.1 }} \pm \overline{0.2, \mathrm{D} 2: 3.9} \pm \overline{0.2, \mathrm{D} 3: 4.2} \pm \overline{0.2 \text {, D4: 4.9 }} \pm \overline{0.2, \mathrm{D} 5: 5.5} \pm \overline{0.2, \mathrm{D} 6: 6.8} \pm \overline{0.2, \mathrm{D} 7: 8.1} \pm \overline{0.2, \mathrm{D} 8: 9.6} \pm \overline{0.2, \mathrm{D} 9: 10.2} \pm \overline{0.2, \mathrm{D} 10: 10.9} \pm \overline{0.2}$ D11: 11.2 \pm 0.2 , D12: 13.4 \pm 0.2 , D13: 14.7 \pm 0.2 , D14: 18.6 \pm 0.2 , D15: 20.3 \pm 0.2 , D16: 21.03 \pm 0.2 , D17: 46.7 \pm 0.2 .

\section{Robustness}

The robustness of the developed method was determined by analyzing the samples under deliberate change in method parameters, such as change in flow rate $( \pm 0.1 \mathrm{ml} / \mathrm{min}), \mathrm{pH}( \pm 0.2)$ of the buffer, $\%$ HSA concentration and Organic phase $( \pm 2 \%)$. The method was found to be robust for all the parameters tested for USP tailing, USP plate count and \% RSD except for \% HSA and it should be between 0.15 and $2.0 \%$. \% HAS affect the retention of diclofenac.

\section{Limit of Detection and Limit of Quantification}

LOD and LOQ were determined based on signal to noise ratio. The signal-to-ratio of 3:1 was taken as LOD and signal-toratio of 10:1 was taken as LOQ. LOD was found to be $0.42 \mu \mathrm{g} / \mathrm{ml}$ and $0.33 \mu \mathrm{g} / \mathrm{ml}$ while LOQ was $1.26 \mu \mathrm{g} / \mathrm{ml}$ and $0.99 \mu \mathrm{g} / \mathrm{ml}$, respectively for TRA and DIC. The same concentrations were prepared and analyzed in triplicate, as shown in Table 2.

\section{Forced Degradation}

\section{Acid-Induced Degradation}

Initial degradation study was performed in $0.1 \mathrm{~N} \mathrm{HCl}$, observed that the drug was stable or showed negligible degradation. So, increasing in the strength of the acid is needed to get the sufficient degradation from the drug substances. Upon treatment with $1 \mathrm{~N} \mathrm{HCl}$ at $\mathrm{RT}$ for $12 \mathrm{~h}$, sufficient degradation was $9.8 \%$ for TRA and $29 \%$ for DIC observed and it was considered as optimized for specificity. There were five degradant peaks, 3.1 min (D1), 9.6 min (D8) $11.2 \min$ (D11), $13.41 \min$ (D12), 46.7 min (D17) were formed, as shown in Figure 3.

\section{Base-Induced Degradation}

When the drug was exposed to $0.1 \mathrm{~N} \mathrm{NaOH}$, sufficient degradation was not observed hence a severe condition of $1 \mathrm{~N}$ $\mathrm{NaOH}$ was chosen as stress condition. The drug degradation was $12.3 \%$ for TRA and $7.9 \%$ for DIC in $48 \mathrm{~h}$ with two impurities i.e. $3.120 \mathrm{~min}$ (D1), $4.800 \mathrm{~min}$ (D4), as shown in Figure 4.

\section{Neutral Hydrolysis}

The degradation of $11.2 \%$ degradation was observed for TRA after 5 days at room temperature, but no degradation was observed for DIC. A total two impurities i.e. $4.02 \mathrm{~min}$ (D2), 4.80 min (D4), as shown in Figure 8.

\section{Hydrogen Peroxide-Induced Degradation}

Both TRA and DIC showed negligible / no degradation in $3 \% \mathrm{H}_{2} \mathrm{O}_{2}$ for 5 days and hence severe stress condition of $3 \%$ $\mathrm{H}_{2} \mathrm{O}_{2}$ was used. The TRA showed $14.5 \%$ and DIC showed 9.6\% degradation at 3days. Three degradants were formed i.e. $2.7 \mathrm{~min}$ (D1), $3.96 \mathrm{~min}$ (D2), $20.360 \mathrm{~min}$ (D15), as shown in Figure 5. 
<smiles>O=C(O)Cc1ccccc1Nc1c(Cl)cccc1Cl</smiles>

Diclofenac<smiles>O=C1Cc2ccccc2N1c1c(Cl)cccc1Cl</smiles>

Impurity A<smiles>[R]c1cccc(Cl)c1Nc1ccccc1Br</smiles>

Impurity $\mathrm{B}: \mathrm{R} 1=\mathrm{CHO}, \mathrm{R} 2=\mathrm{Cl}$

Impurity $\mathrm{C}: \mathrm{R} 1=\mathrm{CH} 2 \mathrm{OH}, \mathrm{R} 2=\mathrm{Cl}$

Impurity $\mathrm{D}: \mathrm{R} 1=\mathrm{CH} 2-\mathrm{COOH}, \mathrm{R} 2=\mathrm{Br}$<smiles>O=C1Cc2ccccc2N1</smiles><smiles>COc1cccc(C2CCCCC2CN(C)C)c1</smiles>

Tramadol<smiles>CCC</smiles><smiles>COc1cccc(C2=C(N(C)C)CCCC2)c1</smiles>

Impurity B<smiles>COc1cccc([C@]2(O)CCCC[C@H]2CN(C)C)c1</smiles>

Impurity A (Trans impurity)<smiles>COc1cccc(C2=CCCCC2N(C)C)c1</smiles>

Impurity C

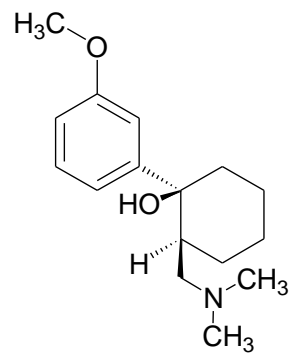

Impurity D

Fig. 1: Structures of Diclofenac and Tramadol and their identified degradants.



Fig. 2: Optimized RP-HPLC Chromatogram of TRA (Rt : 5.9) and DIC (Rt: 26.30). 




Fig. 3: Acid degradation (1N HCl for $12 \mathrm{~h}$ ) chromatogram of TRA and DIC.

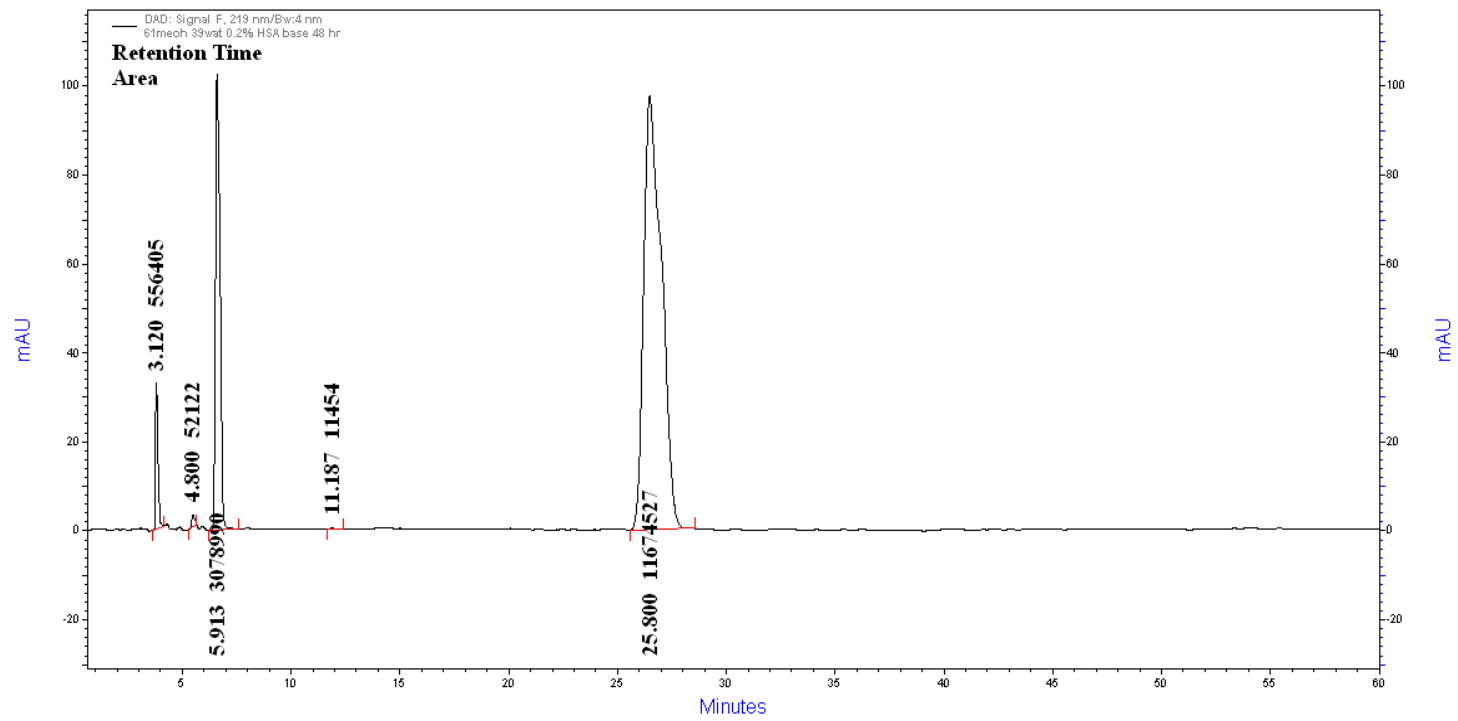

Fig. 4: Base degradation (1N NaOH for $48 \mathrm{~h}$ ) chromatogram of TRA and DIC.



Fig. 5: Oxidative degradation ( $3 \% \mathrm{H}_{2} \mathrm{O}_{2}$ for 3 days) Chromatogram of TRA and DIC. 


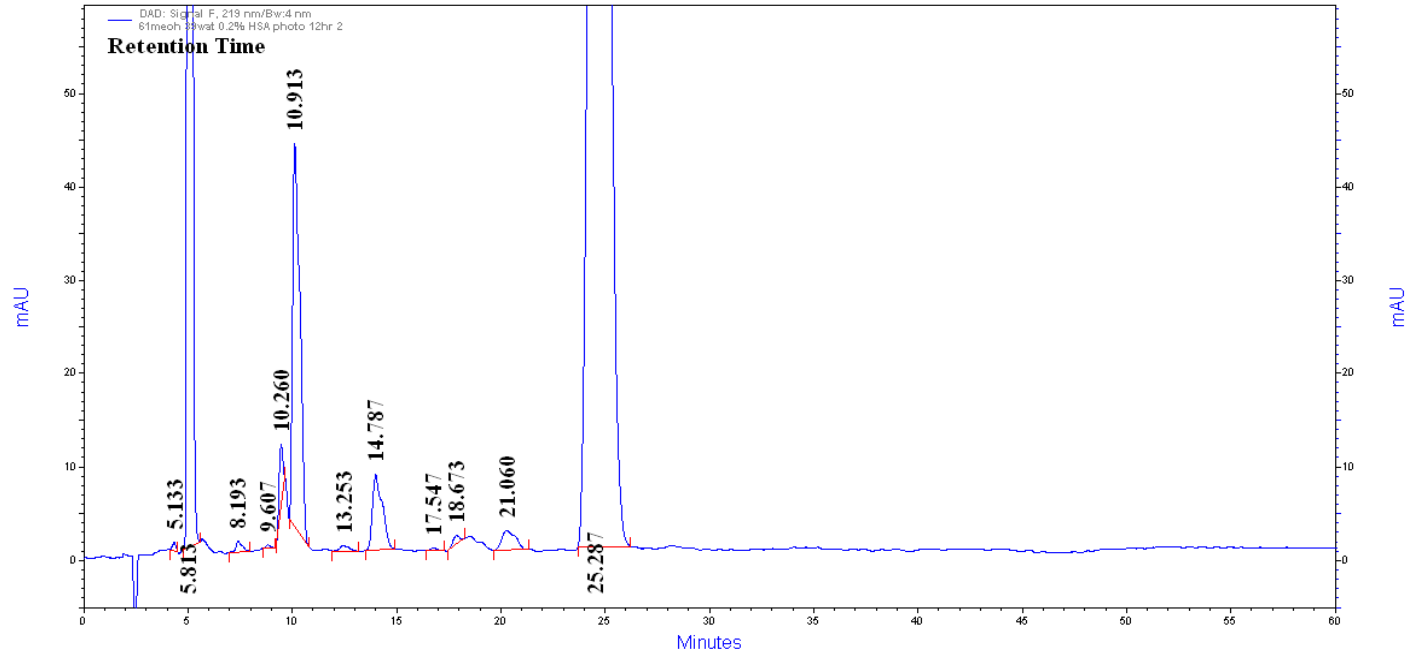

Fig. 6: Photo degradation (sunlight for $12 \mathrm{~h}$ ) chromatogram of TRA and DIC.

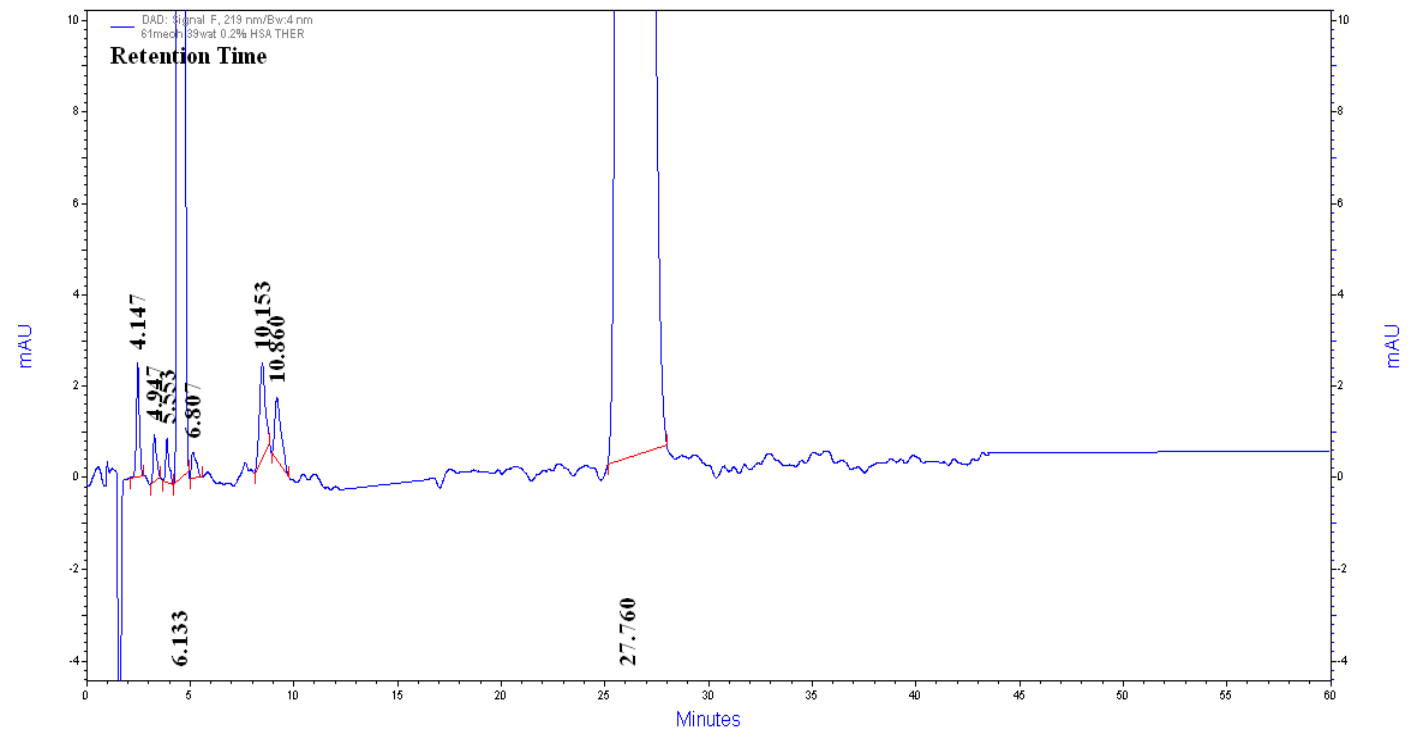

Fig. 7: Thermal degradation $\left(100^{\circ} \mathrm{C}\right.$ for $\left.6 \mathrm{~h}\right)$ chromatogram of TRA and DIC.



Fig. 8: Neutral degradation (in Water for 5 days) chromatogram of TRA and DIC 


\section{Thermal-Induced degradation}

When drugs were exposed to dry heat in oven at $100^{\circ} \mathrm{C}$ for $2 \mathrm{~h}, 6$ degradation products were formed at $4.147 \mathrm{~min}$ (D3), $4.947 \mathrm{~min}$ (D4), $5.553 \mathrm{~min}$ (D5), $6.80 \mathrm{~min}$ (D6), $10.153 \mathrm{~min}$ (D9) and $10.860 \mathrm{~min}$ (D10) with significant change in peak area of the parent drug. The TRA showed $18.6 \%$ and DIC showed $10.3 \%$ of degradation, as shown in Figure 7.

\section{Photochemical Degradation}

Drugs were exposed to photolytic degradation in sunlight for $12 \mathrm{hr}, 15.2 \%$ and $30.4 \%$ degradation was observed for TRA and DIC respectively. Nine degradants were formed at $4.9 \mathrm{~min}$ (D4), $8.1 \mathrm{~min}$ (D7), $9.6 \mathrm{~min}$ (D8), $10.2 \mathrm{~min}$ (D9), $10.9 \mathrm{~min}$ (D10), $13.253 \mathrm{~min}$ (D12), $14.7 \mathrm{~min}$ (D13), $18.673 \mathrm{~min}$ (D14) and 21.03 min (D16), as shown in Figure 6.

\section{DISCUSSION}

For optimization of the chromatographic conditions and to obtain symmetrical peaks with better resolution and peak purity, various conditions such as composition of mobile phase, $\mathrm{pH}$, and different concentrations of ion-pair reagents were tried to achieve suitable condition for simultaneous analysis of Tramadol $\mathrm{HCl}$ and Diclofenac Sodium. In this study, Agilent Qualisil ODS column C18 $(25 \mathrm{~cm} \times 4.6 \mathrm{~mm}$; particle size $5 \mu)$ was used as stationary phase. The flow rate was $1 \mathrm{ml} / \mathrm{min}$ and the photo diode array (PDA) detection wavelength was $219 \mathrm{~nm}$. Various trials with methanol and water as mobile phase $(70: 30 \mathrm{v} / \mathrm{v}$ to 50:50 $\mathrm{v} / \mathrm{v})$ were performed, and TRA was not retained and DIC was observed in between 11 - 28 min with acceptable tailing. To retain TRA, $0.2 \%$ HSA was added to the aqueous phase and the $\mathrm{pH}$ adjusted to $3.0 \pm 0.2$ with orthophosphoric (OPA) acid. HSA selectively retained TRA and not shown effect on DIC. Finally, retention times were optimized to $5.92 \pm 0.1 \mathrm{~min}$ and $26.3 \pm 0.4 \mathrm{~min}$, respectively for TRA and DIC using $39 \%$ of aqueous phase. The method was validated as per ICH Q2 guidelines.

The validated method was used in quantification of TRA and DIC in a variety of stress conditions of acidic, basic, oxidation, photolytic, neutral and thermal degradation. The present stress studies revealed that TRA was more sensitive for thermal whilst DIC degraded drastically under sunlight and acidic stress. However both drugs showed significant degradation in all conditions indicated the labile nature of dosage form during storage conditions. In detailed observation of results, there were few impurities notified in formulation when compared to control. Degradants D8 and D16, respectively under thermal and photolytic conditions were not observed in control. However the rate of degradation for DIC was found to be enhanced under thermal and photolytic degradations and in control DIC degradation declined under acidic stress.

The study revealed that DIC was found to be more labile for photolysis and acid hydrolysis but unaffected in neutral solution, where as TRA was affected all conditions in which negligible degradation was observed under acidic conditions.
While comparing dosage stress of TRA and DIC to control stress conditions, it was observed that degradation rate was increased for DIC under alkaline stress, where as photolytic degradation was also increased. A total of 17 degradants were observed in the present forced degradation study for TRA and DIC. The peak purity of both TRA and DIC was more than 0.999 in all stress conditions investigated. A total of 17 degradants (D1 - D17) were detected in the present study, among them, structures of D2, D9, D10, D12, D14, D15, D16 were identified by Spike analysis (Fig. 1). 3-hydroxybenzoic acid (D2), 3-((dimethyleamino) methyl) cyclohexanone (D9), ( 2 (4-methoxyphenyle) cyclohex-2enyle)N,N-dimethyle methanamine (D10), ( 2- (2,6dichlorophenyleamino) phenyl) methanol (D12), 2(2hydroxyphenyle) acetic acid D(14), 1-(2,6-dichlorophenyle) indolin-2-one D (15), 2,6-dichlorobenzeneamine $\mathrm{D}(16)$ suitably prepared in mobile phase at a concentration of $100 \mu \mathrm{g} / \mathrm{ml}$ and spiked with injection of standards under optimized chromatographic conditions. Retention time of the impurities was compared with the Stress degradation products. It was identified that D2 (3.9 min), D9 (10.2 $\mathrm{min})$ and D10 (10.9 $\mathrm{min})$ belongs to Tramadol HCl, while D12 (13.4 min), D14 (18.6 min), D15 (20.3), D16 (21.03) belongs to Diclofenac Sodium.

\section{CONCLUSION}

A simple, fast and accurate stability indicating RPHPLC-DAD method is described for simultaneous determination of Tramadol $\mathrm{HCl}$ and Diclofenac sodium in pharmaceutical formulations. The developed method was validated by testing its linearity, accuracy, precision, limits of detection and quantitation and specificity. The method is good enough to separate the peaks of active pharmaceutical ingredients (APIs) from the degradation products (produced during forced degradation studies) and concluded that the method can be successfully used for detect and identify any kind of degradants during stability studies of tablet dosage forms.

\section{ACKNOWLEDGMENT}

The authors wish to thank the Hetero laboratories Pvt. Ltd, Hyderabad, India.

\section{Financial support and sponsorship: Nil.}

Conflict of interests: There are no conflicts of interest.

\section{REFERENCES}

Ahmed M, Jalil R, Islam MA, Shaheen SM. Preparation and Stability Study of Diclofenac Sodium Suppositories. Pak J Biol Sci, 2000 3: $1755-1757$.

Ali NW, Hegazy MA, Abdelkawy M, Abdelaleem EA. Simultaneous Determination of Methocarbamol and Ibuprofen or Diclofenac Potassium Using Mean Centering of the Ratio Spectra Method. Acta Pharm, 2012; 62: 191-200.

Anantha KD, Sujan DP, Vijayasree V, Seshagiri rao JVLN. Development and Validation of Dual Wavelength Spectrophotometric 
Method for Simultaneous Estimation of Tramadol Hydrochloride and Diclofenac Sodium in their Combined Dosage Form. Eur J Chem, 2009; 6: 541-554.

Archana, MA, Vishnu C, Kunal Ingale. Development and Validation of a Stability-Indicating LC Method for Simultaneous Analysis of Drotaverine Hydrochloride and Diclofenac Potassium and its Application for Formulation Analysis. Int J Pharma Sci Rev Res, 2012; 12: $132-136$.

Chandra P, Rathore AS, Lohidasan S, Mahadik KR. Application of HPLC for the Simultaneous Determination of Aceclofenac, Paracetamol and Tramadol Hydrochloride in Pharmaceutical Dosage Form. Sci Pharma, 2012; 80: 337-351.

Degwy MA, Aly M, Mamdouh SE. Development and Validation of a HPLC Method for In-Vivo Study of Diclofenac Potassium. Int J Pharm Sci Res, 2013; 4: 622-627.

Gowramma B, Rajan S, Muralidharan S, Meyyanathan SN, Suresh BA. Validated RP-HPLC Method for Simultaneous Estimation of Paracetamol and Diclofenac Potassium in Pharmaceutical Formulation. Int J ChemTech Res, 2010; 2: 676-680.

International Council on Harmonisation (ICH) Harmonized tripartite guidelines. Validation of Analytical Procedures: Text and Methodology. Q2(R1), 1995.

Jadhav SD, Butle SR, Patil SD, Jagtap PK. Validated Stability Indicating RP-HPLC Method for Simultaneous Determination and in Vitro Dissolution Studies of Thiocolchicoside and Diclofenac potassium from Tablet Dosage form. Arabian J Chem, 2015; $8: 118-128$.

Jignesh MP, Prajapati HR. Development and Validation of Derivative Spectrophotometric Method for the Quantitative Estimation of Tramadol Hydrochloride and Aceclofenac in Tablet Dosage Forms. J Pharm Res, 2011; 4: 2950-2953.

Keyur BA, Emanual MP, Falgun AM. Simultaneous Estimation of Tramadol $\mathrm{HCl}$, Paracetamol and Domperidone in Pharmaceutical Formulation by RP-HPLC Method. J Chromatogr Sep Tech, 2012; 3: 1-5

Nag SN, Gouthami B, Madhuri L, Krishnaveni N, Meyyanathan SN, Suresh B. Development and Validation of a RP-HPLC Method for the Simultaneous Determination of Paracetamol and Diclofenac Potassium on Stainless Steel Surface of Pharmaceutical Manufacturing Equipments. J Chem Pharm Res, 2012; 4: 1670-1675. $\begin{array}{ccc}\text { National center for Biotechnology Information.PubChem } \\ \text { Compound } & \text { Database; } & \text { CID }=\end{array}$ https://pubchem.ncbi.nlm.nih.gov/compound/3033(accessed Feb.20,2017)

Panda SS, Patanaik D, Kumar BV. New Stability-Indicating RP-HPLC Method for Determination of Diclofenac Potassium and Metaxalone from their Combined Dosage Form. Sci Pharm, 2012; 80: 127-137.

Patel SA, Prajapati KM. Spectrophotometric Method for the Simultaneous Determination of Chlorzoxazones and Diclofenac Sodium in Synthetic Mixture. Int Res J Pharm, 2012; 3: 293-296.

Patel A, Patel J, Shah A. Development and Validation of First Order Derivative Spectrophotometric Method for Simultaneous Estimation of Tramadol Hydrochloride and Diclofenac Sodium in Tablet Dosage Form. Int J Pharma Sci, 2012; 56: 496-500.

Rajeevkumar SR, Manatragada VR, Sangeeta JS, Raju VK. A Stability Indicating GC-FID Method for Camylofin Dihydrochloride and Diclofenac Potassium in Pharmaceutical Preparation. Int J Pharma Sci, 2011; 4: 317-324.

Rajesh MK, Shrawan GS. Stability-Indicating RP-HPLC Method for Analysis of Paracetamol and Tramadol in a Pharmaceutical Dosage Form. E-J Chem, 2012; 9: 1347-1356.

Rathnam MV, Singh RR. Simultaneous RP HPLC Determination of Camylofin Dihydrochloride and Diclofenac Potassium in Pharmaceutical Preparations. Pharm Anal Acta, 2010; 1: 1-4.

Sarfraz A, Sarfraz M, Ahmad M. Development and Validation of a Bioanalytical Method for Direct Extraction of Diclofenac Potassium from Spiked Plasma. Trop J Pharm Res, 2011; 10: 663-669.

Teja deepthi M, Ramalingam P, Ravindra Reddy J. A New Validated RP-HPLC Method for Simultaneous Determination of Tramadol Hydrochloride and Diclofenac Sodium in Pharmaceutical Dosage Form. Inventi Rapid: Pharma Anal Qual Assu, (2013); 2: 1-8.

\section{How to cite this article:}

Peraman R, Rao DS, Kadiri RR, Bommireddy AR. Stabilityindicating RP-HPLC-DAD method for the simultaneous estimation of Tramadol $\mathrm{HCl}$ and Diclofenac sodium. J App Pharm Sci, 2017; 7 (09): 085-093. 